\title{
Presence of Rhodanese in the Cytosolic Fraction of the Fruit Bat (Eidolon helvum) Liver
}

\author{
Femi Kayode Agboola* and Raphael Emuebie Okonji \\ Department of Biochemistry, Obafemi Awolowo University, Ile-Ife, Nigeria
}

Received 24 June 2002, Accepted 19 August 2003

\begin{abstract}
Rhodanese was isolated and purified from the cytosolic fraction of liver tissue homogenate of the fruit bat, Eidolon helvum, by using ammonium sulphate precipitation and CM-Sephadex C-50 ion exchange chromatography. The specific activity was increased 130-fold with a $53 \%$ recovery. The $K_{m}$ values for $\mathrm{KCN}$ and $\mathrm{Na}_{2} \mathrm{~S}_{2} \mathrm{O}_{3}$ as substrates were $13.5 \pm 2.2 \mathrm{mM}$ and $19.5 \pm 0.7 \mathrm{mM}$, respectively. The apparent molecular weight was estimated by gel filtration on a Sephadex G-100 column to be 36,000 Da. The optimal activity was found at a high $\mathrm{pH}(\mathrm{pH} 9.0)$ and the temperature optimum was $35^{\circ} \mathrm{C}$. An Arrhenius plot of the heat stability data consisted of two linear segments with a break occurring at $35^{\circ} \mathrm{C}$. The apparent activation energy values from these slopes were $11.5 \mathrm{kcal} / \mathrm{mol}$ and $76.6 \mathrm{kcal} /$ mol. Inhibition studies on the enzyme with a number of cations showed that $\mathrm{Mg}^{2+}, \mathrm{Mn}^{2+}, \mathrm{Ca}^{2+}$, and $\mathrm{Co}^{2+}$ did not affect the activity of the enzyme, but $\mathrm{Hg}^{2+}$ and $\mathrm{Ba}^{2+}$ inhibited the enzyme.
\end{abstract}

Keywords: Cyanide, Detoxication, Fruit bat, Liver, Rhodanese

\section{Introduction}

Cyanide is known to be one of the most toxic substances present in a wide variety of food materials that are consumed by mammals (Montgomery, 1965). Many are known to contain cyanogenic glucosides, which upon hydrolysis, release cyanide (Wokes and Willimott, 1951).

Rhodanese (thiosulphate: cyanide sulphur transferase, E.C. 2.8.1.1) catalyses the formation of thiocyanate from free cyanide and a sulphur donor. It has been studied from variety of sources, which include bacteria, yeast, plants, and animals (Cosby and Summer, 1945; Himwich and Saunders, 1948;

*To whom correspondence should be addressed.

Tel: Fax: 08034738078

E-mail: fkagboola@yahoo.co.uk
Sorbo, 1951; Jarabak and Westley, 1974; Anosike and Ugochukwu, 1981; Lee et al., 1995). It is a heat labile enzyme with an optimum $\mathrm{pH}$ of 8.0 and an average molecular weight of about 37,000. The enzyme represents the chief site of detoxication of cyanide and occurs in all parts of the body with the highest concentration in the mitochondrial fraction of the liver of mammals. The main physiological function of rhodanese in mammalian tissues, where it is localized in the mitochondria, is the supply of sulphide for the formation of an iron sulphur centres for the election transport chain. The ability to detoxify cyanide may be only a secondary physiological benefit (Oke, 1973; White et al., 1981).

Fruit bat, Eidolon helvum, feeds basically on fruits, which may include cyanogenic fruits. It is plausible to assume that it possesses an efficient mechanism for cyanide detoxication. This paper describes the isolation and characterization of rhodanese from the cytosolic fraction of a fruit bat liver.

\section{Materials and Methods}

Sodium chloride, sodium thiosulphate (pentahydrate), nitric acid, ammonium sulphate (enzyme grade), glycine, sodium acetate, and ferric nitrate (nonahydrate) were obtained from BDH Chemical Limited (Poole, England). The $\beta$-mercaptoethanol, urea, ethanol, methanol, and phosphoric acid were also products of BDH Chemicals Limited. Ethylenediamine tetraacetic acid (EDTA), citric acid, $\varepsilon$-amino-n-caproic acid, sodium borate, boric acid, bovine serum albumin (BSA), and Coomassie Brilliant-Blue G-250 were obtained from Sigma Chemical Company (St. Louis, USA). CMSephadex C-50, and Sephadex G-100, Sephadex G-25 were obtained from Pharmacia Fine Chemical (Uppsala, Sweden). All of the other reagents were of analytical grade and obtained from either Sigma or BDH.

Bats were collected at the Botanical Garden of the Obafemi Awolowo University, Ile-Ife, Nigeria.

Enzyme and protein assays Rhodanese activity was measured routinely according to the method of Lee et al. (1995). The reaction mixture consisted of a $25 \mathrm{mM}$ borate buffer ( $\mathrm{pH} 9.4), 0.5 \mathrm{M} \mathrm{KCN}$, 
$0.5 \mathrm{M} \mathrm{Na}_{2} \mathrm{~S}_{2} \mathrm{O}_{3}$, and $20 \mu \mathrm{l}$ and of appropriately diluted enzyme solution in a total volume of $1.0 \mathrm{ml}$. The mixture was incubated for $1 \mathrm{~min}$ at room temperature and the reaction was stopped by the addition of $0.5 \mathrm{ml}$ of $15 \%$ formaldehyde, followed by the addition of $1.5 \mathrm{ml}$ of Sorbo reagent (containing $10 \mathrm{~g} \mathrm{Fe}\left(\mathrm{NO}_{3}\right)_{2} 9 \mathrm{H}_{2} \mathrm{O}$, and $20 \mathrm{ml} \mathrm{HNO}_{3}$ (sp.g 1.40) and distilled water to $100 \mathrm{ml}$ ) (Sorbo, 1951). The absorbance was then read at $460 \mathrm{~nm}$. The activity was expressed in rhodanese unit (RU). One rhodanese unit was taken as the amount of enzyme, which under the given condition, produced an optical density reading of 1.08 at $460 \mathrm{~nm}$ per min (Sorbo, 1951). Protein concentrations were determined by the method of Bradford (1976) using bovine serum albumin (BSA) as the standard.

Enzyme isolation and purification All operations were carried out at temperatures between $0-10^{\circ} \mathrm{C}$ either in a cold room or ice bucket for the entire time. All of the buffers contained $10 \mathrm{mM}$ sodium thiosulphate to stabilize the enzyme. The $\mathrm{pH}$ measurement was made at $25^{\circ} \mathrm{C}$ using a Kenway Model $3015 \mathrm{pH}$ meter.

Crude extract The animals were knocked on the back of their heads to unconsciousness and the liver quickly excised and stored in the refrigerator until required. The frozen liver was thawed at room temperature and rinsed several times with cold saline $(0.9 \%$ $\mathrm{NaCl}$ at $\mathrm{pH}$ 7.4) to remove blood and other impurities, and then weighed. In a typical extraction process, approximately $95 \mathrm{~g}$ of tissue (collected from twelve bats) was used for the preparation. The liver was minced with scissors into smaller pieces and homogenized in 2 volumes of $0.1 \mathrm{M}$ acetate glycine buffer, $\mathrm{pH} 7.8$ containing $1 \mathrm{mM} \varepsilon$-amino-n-caprioc acid, and $10 \mathrm{mM}$ sodium thiosulphate (Buffer A) in a blender. The homogenate was centrifuged for $15 \mathrm{~min}$ at $10,000 \mathrm{rpm}$ at $6^{\circ} \mathrm{C}$. The supernatant was filtered through a double layer of cheesecloth. The cellular debris was resuspended in one volume of the homogenization buffer, homogenized in a blender, and centrifuged under the same condition. The obtained supernatant was combined with that from the first centrifugation step.

Ammonium sulphate fractionation The combined supernatant was brought to $65 \%$ ammonium sulphate saturation $(430 \mathrm{~g} / \mathrm{l})$ by the addition of solid ammonium sulphate over a period of 1 hour with continuous stirring, and then left overnight. The resulting precipitate was collected by centrifugation at $6,000 \mathrm{rpm}$ for $30 \mathrm{~min}$ and immediately dialyzed against several changes of a $50 \mathrm{mM}$ citrate buffer, pH 5.0 containing $10 \mathrm{mM} \mathrm{Na} \mathrm{S}_{2} \mathrm{O}_{3}$ (buffer B). The dialysate was centrifuged at $6,000 \mathrm{rpm}$ for $30 \mathrm{~min}$ to remove insoluble materials.

CM-Sephadex ion exchange chromatography CM-Sephadex C-50 was pretreated by first swelling $10 \mathrm{~g}$ of the resin in 11 of distilled water for $3 \mathrm{~d}$. The resin was then washed with $1 \mathrm{M} \mathrm{KCl}$ (2 l) in a series of stirring and decantation processes. It was later washed with $0.1 \mathrm{M} \mathrm{KOH} \mathrm{(2} \mathrm{l)} \mathrm{and} \mathrm{0.1} \mathrm{M} \mathrm{HCL} \mathrm{(2} \mathrm{l).} \mathrm{Distilled} \mathrm{water}$ was used to rinse the resin between each washing.

The resin was packed into a $2.5 \times 40$ column and equilibrated with buffer B. The dialyzed protein from the preceding step was layered on the column. The column was first washed with $200 \mathrm{ml}$ buffer $\mathrm{B}$ to wash the unbound protein, followed by elution with a $250 \mathrm{ml}$ linear gradient of $0-0.5 \mathrm{M} \mathrm{KCl}$ in buffer B. Fractions of $5 \mathrm{ml}$ were collected at a rate of $36 \mathrm{ml} / \mathrm{h}$. The protein profile was monitored spectrophotometrically at $280 \mathrm{~nm}$. The fractions were also assayed for enzyme activity. The active fractions were pooled and brought to $70 \%$ ammonium sulphate saturation.

Polyacrylamide gel electrophoresis (PAGE) Polyacrylamide gel electrophoresis in the absence of sodium dodecyl sulphate (SDS) was carried out according to the method described in the Pharmacia's Manual (Polyacrylamide Gel Electrophoresis, Laboratory Techniques) on $7.5 \%$ rod gel. The protein sample was first desalted on a Bio-Gel P-10 column using a $10 \mathrm{mM}$ phosphate buffer, $\mathrm{pH} 7.0$, containing $10 \mathrm{mM}$ sodium thiosulphate (buffer D) as the eluent. To $50 \mu \mathrm{l}$ of the sample was added $50 \mu \mathrm{l}$ bromophenol blue $(0.05 \%$ bromophenol blue in $0.01 \mathrm{M}$ sodium phosphate buffer, $\mathrm{pH} 7.0$ ). An aliquot of $10 \mu \mathrm{l}$ of the mixture was applied on a gel. The gels were run at $8 \mathrm{~mA}$ per gel and stained for the protein after electrophoresis. Also, SDSpolyacrylamide gel electrophoresis (SDS-PAGE) was performed for the purpose of ascertaining purity of the preparation according to the procedure of Weber and Osborn (1975) on 10\% rod gels using the phosphate buffer system. The protein sample was prepared by the addition of a $0.2 \mathrm{ml}$ sample buffer (containing phosphate buffer, $\mathrm{pH}$ 7.0, $1 \% \mathrm{SDS}$, and 2-mercaptoethanol) to $10 \mu \mathrm{l}$ of the desalted enzyme preparation and heated in a boiling water bath for $2 \mathrm{~min}$. After cooling, $10 \mu \mathrm{l}$ aliquot was applied on a rod gel. Electrophoresis was run at $8 \mathrm{~mA}$ per gel for $5 \mathrm{~h}$.

Molecular weight determination The native molecular weight was determined on a calibrated Sephadex G-100 column $(1.5 \times 40$ $\mathrm{cm})$. The standard proteins were bovine serum albumin $\left(M_{r} 66,000\right)$, ovine albumin $\left(M_{r}\right.$ 45,000), thermolysin $\left(M_{r}\right.$ 37,500) and $\alpha-$ chymotrypsinogen A $\left(M_{r} 25,000\right)$. To calibrate the column, $3 \mathrm{ml}$ of each standard of $3 \mathrm{mg} / \mathrm{ml}$ was applied to the column and run separately. The column was eluted at a flow rate of $8.4 \mathrm{ml} / \mathrm{h}$. The eluent was a $10 \mathrm{mM}$ phosphate buffer, $\mathrm{pH}$ 7.0. Fractions of $2 \mathrm{ml}$ were collected and monitored for protein. The void volume $\left(\mathrm{V}_{\mathrm{o}}\right)$ of the column was determined by the elution volume $\left(\mathrm{V}_{\mathrm{e}}\right)$ of Blue Dextran. A plot of $\mathrm{V}_{\mathrm{e}} / \mathrm{V}_{\mathrm{o}}$ against logarithm of the molecular weight of the marker proteins was made on a semilogarithmic paper.

Determination of kinetic parameters The kinetic parameters $\left(K_{m}\right.$ and $V_{\max }$ ) of the enzyme were determined according to Lee $e t$ al. (1995). The $K_{m}{ }^{K C N}$ was determined by varying the concentration of KCN between $10 \mathrm{mM}$ and $100 \mathrm{mM}$ at $50 \mathrm{mM} \mathrm{Na}_{2} \mathrm{~S}_{2} \mathrm{O}_{3}$. Also, $K_{m}$ for sodium thiosulphate was determined by varying the $\mathrm{Na}_{2} \mathrm{~S}_{2} \mathrm{O}_{3}$ concentration from $50 \mathrm{mM}$ to $500 \mathrm{mM}$ at $50 \mathrm{mM}$ of $\mathrm{KCN}$. The ammonium sulphate precipitate of the enzyme was first desalted on a Bio-gel P10 column using a $10 \mathrm{mM}$ phosphate buffer, $\mathrm{pH} 7.0$ containing $10 \mathrm{mM}$ sodium thiosulphate (buffer D). The kinetic parameters were estimated from the double reciprocal plot (Lineweaver and Burk, 1934).

Effect of temperature on the enzyme To investigate the effect of temperature on the enzyme activity, $20 \mu \mathrm{l}$ of the enzyme $(1.15 \mathrm{mg} /$ $\mathrm{ml}$ ) was assayed at temperatures between $0^{\circ}$ and $70^{\circ} \mathrm{C}$. The assay mixture was first incubated at the indicated temperature for $10 \mathrm{~min}$ before initiating the reaction by the addition of the enzyme that had been equilibrated at the same temperature.

For the effect of heat on enzyme stability, a $1 \mathrm{ml}$ aliquot of the 
Table 1. Purification of rhodanese from bat liver

\begin{tabular}{ccccc}
\hline Step/Fraction & $\begin{array}{c}\text { Total activity } \\
\text { (RU) }\end{array}$ & $\begin{array}{c}\text { Total protein } \\
(\mathrm{mg})\end{array}$ & $\begin{array}{c}\text { Specific activity } \\
(\mathrm{RU} / \mathrm{mg})\end{array}$ & $\begin{array}{c}\text { Yield } \\
(\%)\end{array}$ \\
\hline Crude extract & 29,800 & 6,320 & 4.71 & 100 \\
65\% Ammonium sulphate precipitation & 24,600 & 522 & 47.1 & 83 \\
CM-Sephadex ion exchange & 15,700 & 115 & 137 & 53 \\
\hline
\end{tabular}

Each step was carried out as described in the text. Activity was measured by the rate of formation of thiocyanate. Protein concentration was determined by the method of Bradford. One unit of activity was taken as the amount of enzyme, which under the given condition, produced an OD reading of 1.08 at $460 \mathrm{~nm}$ per min (Sorbo, 1951).

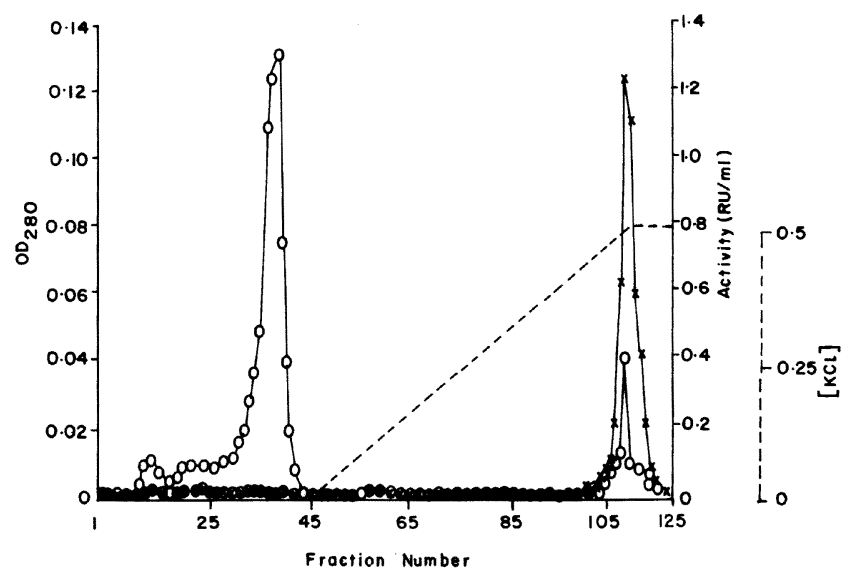

Fig. 1. CM-Sephadex C-50 ion exchange chromatography of fruit bat liver rhodanese. The column was first washed with $200 \mathrm{ml}$ of citrate buffer, $\mathrm{pH} 5.0$, containing $10 \mathrm{mM}$ sodium thiosulphate. The column was further eluted with $250 \mathrm{ml}$ linear salt gradient of $0-0.5 \mathrm{M} \mathrm{KCl}$ at a flow rate of $36 \mathrm{ml} / \mathrm{hr}$. Fractions of $5 \mathrm{ml}$ were collected. $\mathrm{OD}_{280}\left(\bigcirc_{-} \bigcirc\right)$, Enzyme activity $\left(X_{-} \times\right)$, Linear $\mathrm{KCl}$ gradient (--------), Pooled fractions (-).

enzyme solution (previously desalted on a Biogel P10 column) was incubated at the temperature. Next, $20 \mu \mathrm{l}$ aliquot were withdrawn and assayed for residual activity at $10 \mathrm{~min}$ intervals.

Effect of pH on enzyme activity The effect of $\mathrm{pH}$ on the fruit bat liver rhodanese was carried out by assaying the enzyme at different $\mathrm{pH}$ using the following buffers: $0.2 \mathrm{M}$ citrate buffer ( $\mathrm{pH}$ 5.0-6.5), $0.2 \mathrm{M}$ phosphate buffer ( $\mathrm{pH}$ 6.5-8.5), and $0.2 \mathrm{M}$ borate buffer ( $\mathrm{pH}$ 8.5-11.0).

Effect of cations on enzyme activity The effect of various metal ions on the activity of rhodanese was also studied. The salts included mercuric chloride $\left(\mathrm{HgCl}_{2}\right)$, barium chloride $\left(\mathrm{BaCl}_{2}\right)$, calcium chloride $\left(\mathrm{CaCl}_{2}\right)$, borate chloride $\left(\mathrm{BoCl}_{2}\right)$, magnesium chloride $\left(\mathrm{MgCl}_{2}\right)$, and manganese chloride $\left(\mathrm{MnCl}_{2}\right)$ at $0.5 \mathrm{mM}$ and $1.0 \mathrm{mM}$. The final concentration of the salt in the assay mixture was either $250 \mu \mathrm{M}$ or $500 \mu \mathrm{M}$.

\section{Results}

The results of the purification procedures are summarized in

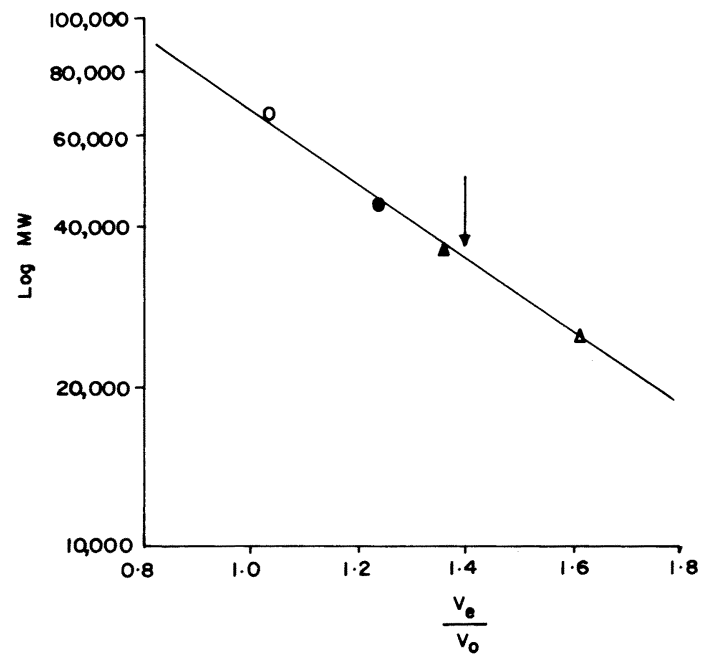

Fig. 2. Calibration curve on Sephadex G-100 for molecular weight determination. $3 \mathrm{ml}$ of the maker proteins was applied to a Sephadex G-100 column $(2.5 \times 100 \mathrm{~cm})$ and eluted by $10 \mathrm{mM}$ phosphate buffer, $\mathrm{pH} 7.0$, at a flow rate of $8.4 \mathrm{ml} / \mathrm{h}$. The $\mathrm{V}_{\mathrm{o}}$ was determined by the elution of $2 \mathrm{mg} / \mathrm{ml}$ solution of Blue Dextran eluted under the same condition. Marker proteins are bovine serum albumin $\left(M_{r}\right.$ 66,000), ovine albumin $\left(M_{r}\right.$ 45,000), thermolysin $\left(M_{r}\right.$ 37,500), and chymotrypsinogen A $\left(M_{r} 25,000\right)$. The arrow indicates the position of the fruit bat liver rhodanese.

Table 1. During the purification, the enzyme was stabilized by the presence of sodium thiosulphate. Figure 1 shows the elution profile after the CM-Sephadex C-50 ion exchange chromatography. The specific activity of the pure enzyme was $137 \mathrm{RU} / \mathrm{mg}$.

Only one protein band was observed after gel electrophoresis of the purified rhodanese, either in the presence or absence of sodium dodecyl sulphate (Figures not shown). Gel filtration on the Sephadex G-100 column resulted in an apparent molecular weight of about 36,000 Da (Fig. 2).

The Lineweaver-Burk plots for the determination of kinetic parameters $\left(K_{m}\right.$ and $\left.V_{\max }\right)$ of the fruit bat liver rhodanese are shown in Figures $3 \mathrm{a}$ and $3 \mathrm{~b}$. Table 2 shows the summary of the $K_{m}$ and $V_{\max }$ values for the substrates. A comparison of fruit bat rhodanese with some other mammalian enzymes is shown in Table 3.

The optimum temperature for rhodanese activity was $35^{\circ} \mathrm{C}$. 
(A)

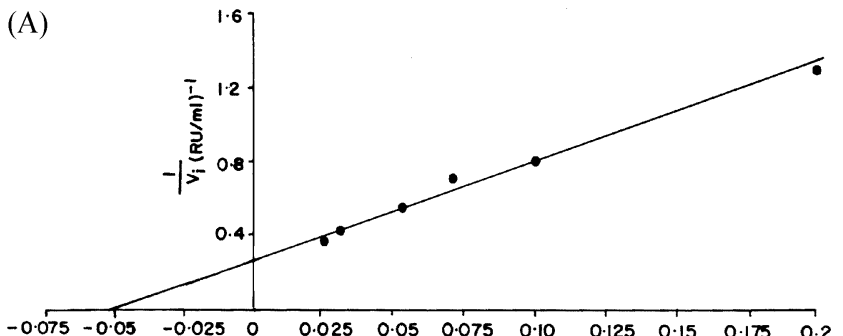

$$
\frac{1}{\left[\mathrm{No}_{2} \mathrm{~S}_{2} \mathrm{O}_{3}\right]} \mathrm{mM}^{-1}
$$

(B)

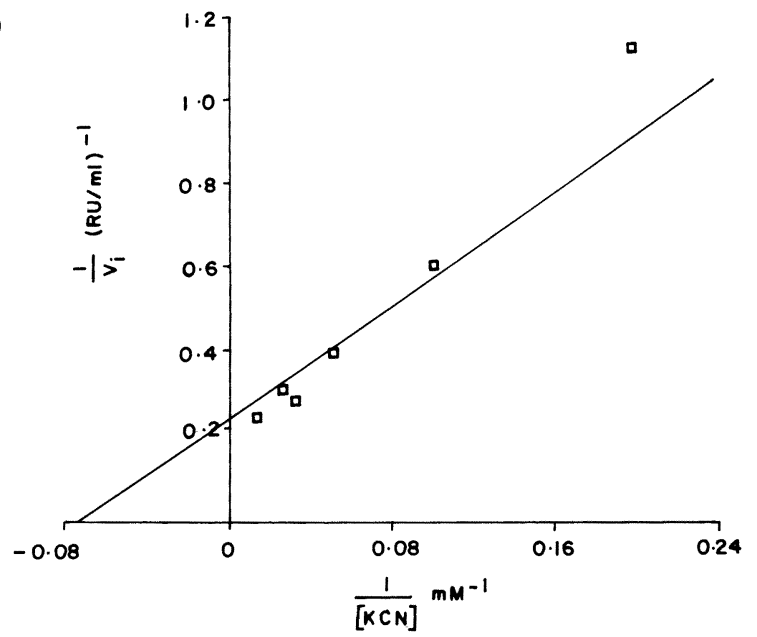

Fig. 3. Lineweaver-Burk plot for the determination of the kinetic parameters. Enzyme was assayed at varying concentrations of $\mathrm{Na}_{2} \mathrm{~S}_{2} \mathrm{O}_{3}$ at $50 \mathrm{mM} \mathrm{KCN} \mathrm{(A)} \mathrm{and} \mathrm{varying} \mathrm{concentrations} \mathrm{of} \mathrm{KCN}$ at $50 \mathrm{mM} \mathrm{Na} \mathrm{S}_{2} \mathrm{O}_{3}$ (B). The reaction mixture also contained $25 \mathrm{mM}$ borate buffer, $\mathrm{pH} 9.4$, and $20 \mu \mathrm{l}$ of the enzyme in a total volume of $1.0 \mathrm{ml}$ at $25^{\circ} \mathrm{C}$.

An Arrhenius plot of the effect of temperature on enzyme activity at pH 9.4 is biphasic (Fig. 4). The apparent activation energy values estimated from the two slopes were $11.5 \mathrm{kcal} /$ $\mathrm{mol}$ and $76.6 \mathrm{kcal} / \mathrm{mol}$. Figure 5 shows the effect of temperature on enzyme stability. The influence of $\mathrm{pH}$ on the rate of rhodanese activity is shown in Fig. 6. An optimum $\mathrm{pH}$ of 9 was obtained. The result of the effect of various salts on the activity of rhodanese is presented in Table 4.
Table 2. Kinetic Parameters of fruit bat liver rhodanese

\begin{tabular}{ccc}
\hline Substrate & $K_{m}(\mathrm{mM})$ & $V_{\max }(\mathrm{RU} / \mathrm{mL})$ \\
\hline $\mathrm{KCN}$ & $13.5 \pm 2.2$ & $6.5 \pm 0.5$ \\
$\mathrm{Na}_{2} \mathrm{~S}_{2} \mathrm{O} 3$ & $19.5 \pm 0.7$ & $3.7 \pm 0.2$ \\
\hline
\end{tabular}

The $K_{m}$ and $V_{\max }$ values are means of five determinations. The kinetic parameters $\left(K_{m}\right.$ and $\left.V_{\max }\right)$ for the two substrates were determined by varying the concentrations of $\mathrm{KCN}$ (between $10 \mathrm{mM}$ and $100 \mathrm{mM}$ ) at a fixed $50 \mathrm{mM} \mathrm{Na}_{2} \mathrm{~S}_{2} \mathrm{O}_{3}$ and also varying the concentrations of $\mathrm{Na}_{2} \mathrm{~S}_{2} \mathrm{O}_{3}$ (between $50 \mathrm{mM}$ and $500 \mathrm{mM}$ ) at a fixed $\mathrm{KCN}$ concentration of $50 \mathrm{mM}$. The kinetic parameters were determined from the double reciprocal plots.

\section{Discussion}

Several animals are able to thrive on cyanogenic plants, due primarily to inherent cyanide detoxifying mechanisms of the organisms. Rhodanese and 3-mercaptopyruvate sulphurtransferase (3-MST) represent the chief enzymes of cyanide detoxification (Westley, 1980; Nagahara et al., 1999). This research shows the existence of rhodanese in the cytosolic fractions of the fruit bat liver homogenate. The enzyme was purified further to apparent homogeneity by ammonium sulphate precipitation and ion-exchange chromatography on CM-Sephadex. Fruit bats feed on a wide variety of ripe fruits (Mutere, 1965; Halstead and Segun, 1975; Okon et al., 1976). Many fruits contain prussic acid (hydrogen cyanide) (Montgomery, 1965). Since hydrogen cyanide spray was unsuccessful in controlling fruit bats in East Africa (Constantine, 1970), this provides further evidence of the presence of a powerful mechanism for the detoxication of cyanide in this animal. In another set of experiments that are ongoing in our laboratory, it has been shown that 3-MST is also abundant in the cytosolic fraction of the fruit bat liver.

The specific activity of this preparation was $137 \mathrm{RU} / \mathrm{mg}$ with a 53\% yield. Sorbo (1953a, 1953b) obtained 256 RU/mg for bovine liver rhodanese. Lee et al. (1995) reported a value of $1,076 \mathrm{RU} / \mathrm{mg}$ for the mitochondrial enzyme from mouse liver. From human liver, 1240 RU/mg was obtained (Jarabak and Westley, 1974).

Table 3. Comparison of $K_{m}$ values for fruit bat liver and other mammalian liver rhodaneses

\begin{tabular}{cccccc}
\hline \multirow{2}{*}{ Substrate } & \multicolumn{5}{c}{$K_{m}(\mathrm{mM})$} \\
\cline { 2 - 6 } & Fruit bat $^{\mathrm{a}}$ & Mouse $^{\mathrm{b}}$ liver & Bovine $^{\mathrm{c}}$ liver & Human $^{\mathrm{d}}$ liver & Rat $^{\mathrm{e}}$ liver \\
\hline $\mathrm{KCN}$ & 13.5 & 12.5 & 19.0 & 9.5 & NA \\
$\mathrm{Na}_{2} \mathrm{~S}_{2} \mathrm{O}_{3}$ & 19.5 & 8.3 & 6.7 & 4.5 & 4.4 \\
\hline
\end{tabular}

The $K_{m}$ values of fruit bat liver rhodanese are compared with those of the enzyme from other mammalian sources. (a) This work in 50 $\mathrm{mM}$ borate, $\mathrm{pH} 9.4,25^{\circ} \mathrm{C}$ (b) Lee et al. (1995) in $50 \mathrm{mM}$ borate, $\mathrm{pH} 9.4,25^{\circ} \mathrm{C}$ (c) Sorbo (1953a) in $40 \mathrm{mM}$ phosphate, $\mathrm{pH} 8.6,25^{\circ} \mathrm{C}$ (d) Jarabak and Westley (1974) in $0.1 \mathrm{M}$ glycine, $\mathrm{pH} 9.1,25^{\circ} \mathrm{C}$ (e) Nagahara et al. (1996) in $40 \mathrm{mM}$ phosphate, pH 8.6, $25^{\circ} \mathrm{C} . \mathrm{NA}$ means not available. 


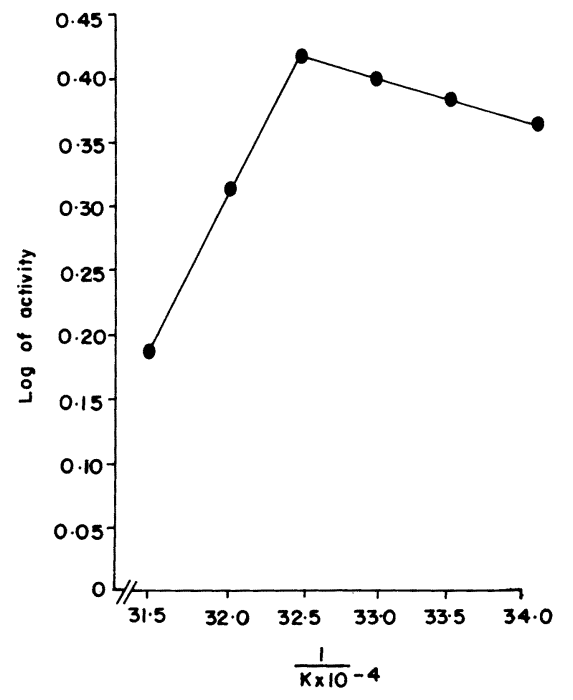

Fig. 4. Effect of temperature on the activity of rhodanese. Arrhenius plot (logarithm of activity (RU/ml)) against the reciprocal of the incubation temperature in Kelvin. $20 \mathrm{ml}$ aliquot of the enzyme was assayed at temperatures between $0^{\circ} \mathrm{C}$ and $70^{\circ} \mathrm{C}$. The assay mixture was first incubated at the indicated temperature for 10 mins before initiating the reaction by the addition of the enzyme. Assays were in a $25 \mathrm{mM}$ borate buffer, $\mathrm{pH} 9.4$.

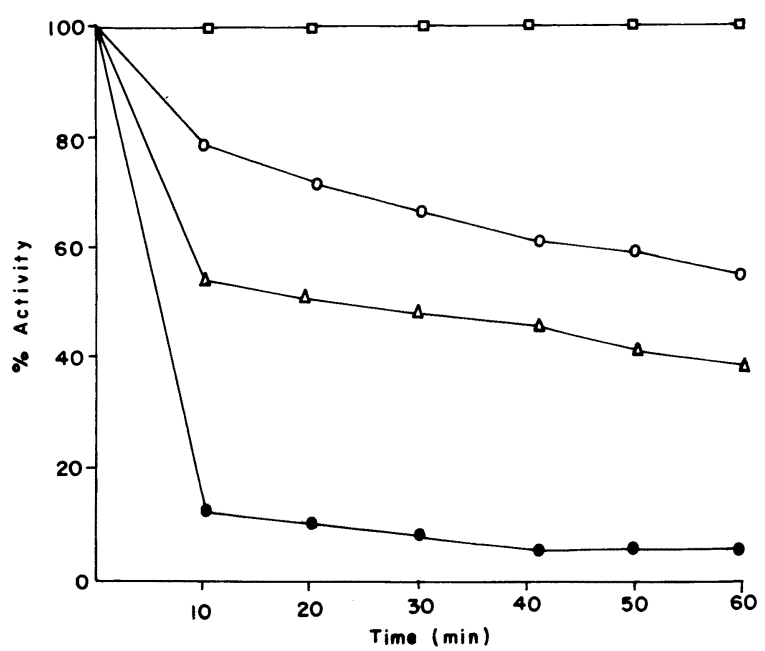

Fig. 5. Effect of temperature on the stability of fruit bat rhodanese. An enzyme solution of $1.0 \mathrm{ml}(1.15 \mathrm{mg} / \mathrm{ml})$ was incubated at the indicated temperature and aliquots were withdrawn at various times (as indicated) and assayed for residual enzyme activity. The activity at $30^{\circ} \mathrm{C}(\square), 40^{\circ} \mathrm{C}(\bigcirc), 50^{\circ} \mathrm{C}(\triangle)$, and $60^{\circ} \mathrm{C}(\bigcirc)$ was expressed as a percentage of the activity of the enzyme at $30^{\circ} \mathrm{C}$ (control). Assays were in $25 \mathrm{mM}$ borate buffer, $\mathrm{pH} 9.4$.

The apparent relative molecular weight of $36,000 \mathrm{Da}$ compares very well with that reported for the enzyme from other sources (Sorbo, 1953a, 1953b; Jarabak and Westley, 1974; Lee et al., 1995). The results of the kinetic studies are similar to that of the enzyme from some mammalian sources (Table 3). It is noted, however, that the $K_{m}$ values for

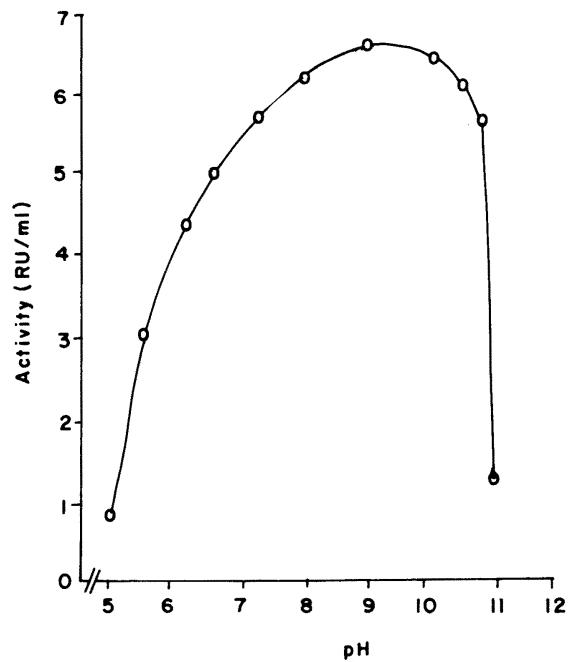

Fig. 6. Effect of $\mathrm{pH}$ on fruit bat liver rhodanese. The assay

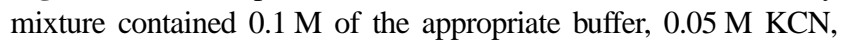
$0.05 \mathrm{M} \mathrm{Na}_{2} \mathrm{~S}_{2} \mathrm{O}_{3}$, and $0.02 \mathrm{ml}$ of the enzyme solution in a final volume of $1.0 \mathrm{ml}$. The buffers and their respective $\mathrm{pH}$ ranges were: $0.2 \mathrm{M}$ citrate buffer, $(\mathrm{pH}$ 5.0-6.5), $0.2 \mathrm{M}$ phosphate buffer (pH 7.0-8.5), and 0.2 M borate buffer, ( $\mathrm{pH} 9.0-11)$.

Table 4. Effect of salt's metal ions on bat liver rhodanese

\begin{tabular}{ccc}
\hline \multirow{2}{*}{ Salt } & \multicolumn{2}{c}{ Enzyme activity (\%) } \\
\cline { 2 - 3 } & $250 \mu \mathrm{M}$ & $500 \mu \mathrm{M}$ \\
\hline None & $100 \pm 0$ & $100 \pm 0$ \\
$\mathrm{MgCl}_{2}$ & $88 \pm 4$ & $90 \pm 5$ \\
$\mathrm{MnCl}_{2}$ & $86 \pm 5$ & $86 \pm 5$ \\
$\mathrm{CoCl}_{2}$ & $85 \pm 2$ & $85 \pm 2$ \\
$\mathrm{CaCl}_{2}$ & $78 \pm 3$ & $72 \pm 3$ \\
$\mathrm{HgCl}_{2}$ & $49 \pm 2$ & $44 \pm 2$ \\
$\mathrm{BaCl}_{2}$ & $46 \pm 2$ & $42 \pm 4$ \\
\hline
\end{tabular}

Enzyme assay was carried out using the standard assay mixture containing each salt at final concentrations of $250 \mu \mathrm{m}$ and $500 \mu \mathrm{m}$. The values are the means of triplicate determinations.

thiosulphate of the enzymes from the liver of this fruit bat and that of bovine liver i.e. $19.5 \mathrm{mM}$ and $6.7 \mathrm{mM}$ respectively (see Table 3) are different. This may indicate that the affinity of the enzyme from a fruit bat liver for thiosulphate is less than that of the bovine liver enzyme. It has been observed that ruminants were more susceptible to the effect of cyanogenic plants than monogastric animals (Kingsbury, 1964). A number of roles other than detoxication of cyanide have been assigned to the enzyme, depending on the tissue/organ concerned. White et al. (1981) reported that the main physiological role of rhodanese is the supply of sulphide for the formation of an iron sulphur center for the electron transport chain in mammalian tissues, while the ability to detoxify cyanide may be only a secondary benefit. Tomati et al. (1974) suggested the reactivation of ferredoxin from apoferredoxin by rhodanese. Ali et al. (2001) suggested that the function of 
rhodanese in cattle is the protection of the respiratory chain in the case of cyanide toxicity.

The $\mathrm{pH}$ optimum is in good agreement with that from bovine liver, which is between 8.0 and 9.0 (Sorbo, 1953a, 1953b). Chew and Boey (1972), working on the tapioca leaf, obtained a high $\mathrm{pH}$ value of 10.2-11, while Lee et al. (1995) reported a $\mathrm{pH}$ of 9.4 for mouse liver rhodanese. Lang (1933a) showed the presence of heat labile enzyme of optimum temperature of $38^{\circ} \mathrm{C}$ in a rat liver. Himwich and Saunders (1948), working on bovine liver rhodanese, obtained an optimum temperature between $38^{\circ} \mathrm{C}$ and $40^{\circ} \mathrm{C}$. Sorbo (1953a, $1953 \mathrm{~b}$ ) also reported an optimum temperature of $50^{\circ} \mathrm{C}$ from bovine liver. Chew and Boey (1972) obtained an optimum temperature between $57^{\circ} \mathrm{C}$ and $59^{\circ} \mathrm{C}$ from the rhodanese of tapioca leaves. Vaughan (1972) and Halstead and Segun (1975) showed that fruit bats do not hibernate, but maintain their body temperature within narrow limits by physiological and behavioral means; they are homoiothermic. Thus the optimum temperature of $35^{\circ} \mathrm{C}$ obtained for the fruit bat liver rhodanese, which is the same temperature suggesting a conformational change in the enzyme (i.e. the point of break in the Arrhenius plot), is an indication of the effect of structural change due to temperature change. The apparent activation energy value of $11.5 \mathrm{kcal} / \mathrm{mol}$ from the Arrhenius plot was a little higher than the $7.5 \mathrm{kcal} / \mathrm{mol}$ that was reported for bovine liver rhodanese (Sorbo, 1953a). This value, however, falls within the physiological activation energy range $(1-25 \mathrm{kcal} / \mathrm{mol})$ for physiological processes in living organisms (Fruton and Summonds, 1963). The second value of $76.6 \mathrm{kcal} / \mathrm{mol}$ lies within the range $(40 \mathrm{kcal} / \mathrm{mol}$ to $100 \mathrm{kcal} / \mathrm{mol}$ ) for protein denaturation. These results, combined with the result that the enzyme was stable up to $45^{\circ} \mathrm{C}$, suggests that rhodanese from fruit bat will be most active under the body temperature because there will be no time when the fruit bat will be exposed to a temperature that is higher than $45^{\circ} \mathrm{C}$, since $E$. helvum is a tropical animal (Mutere, 1965; Vaughan, 1972).

Metal ions, such as $\mathrm{Cu}^{2+}$ and $\mathrm{Fe}^{2+}$, have been reported to significantly inhibit rhodanese (Lang, 1933a, 1933b). Metal ions showing inhibitions are those that have strong affinity for ligands, such as the phosphate, cysteinyl, and the histidyl side chain of protein (Vallee and Ulmer, 1972; Stokinger, 1984). The inhibition of fruit bat liver rhodanese by $\mathrm{Hg}^{2+}$ and $\mathrm{Ba}^{2+}$ is probably due to the interaction of these metal ions with sulphydryl groups at the enzyme catalytic site (Vallee and Ulmer, 1972; Lee et al., 1995; Nagahara and Nishino,1996).

Acknowledgment The authors are indebled to Prof. Adeyuka Afolayan for invaluable suggestions, advice, discussion and the use of his equipment and reagents.

\section{References}

Al-Qarawi, A. A., Mousa, H. and Ali, B. H. (2001) Tissue and intracellular distribution of rhodanese and mercaptopyruvate sulphurtansferase in ruminants and birds. Vet. Res. 32, 63-70.

Anosike, E. O. and Ugochukwu, E. N. (1981) Characterization of rhodanese from cassava leaves and tubers. J. Exp. Bot. 32, 1021-1027.

Bradford, K. M. (1976) A rapid and sensitive method for the quantitation of microgram quantities of protein utilizing the principle of protein-dye binding. Anal. Biochem. 72, 248-254.

Chew, M. Y. and Boey, C. G. (1972) Rhodanese of tapiocal leaf. Phytochem. 11, 167-160.

Constantine, D. G. (1970) Bats in Relation to food; in Biology of Bat, Wimsatt, W. A. (ed.) Vol. II, pp. 96-398.

Cosby, E. Q. and Summer, J. B. (1945) Rhodanese. Arch. Biochem. 7, 457-460.

Fruton, J. S. and Simmonds, S. (1963) Kinetics of enzyme, General Biochemistry, 2nd ed., pp. 244-283, John Wiley and Sons, New York, USA.

Halstead, L. B. and Segun, A. O. (1975) Fruit bat, Eidolon helvum 3; in Dissection guides of common tropical animals, $\mathrm{p}$. 58, Ethiope Pub. House Benin City, Nigeria.

Himwich, W. A. and Saunders, J. B. (1948) Enzymatic conversion of cyanide to thiocyanate Amer. J. Physiol. 53, 348-354.

Jarabak, R. and Westley, J. (1974) Human Liver rhodanese. Non linear Kinetic behavior in a double displacement mechanism. Biochem. 13, 3233-3242.

Kingsbury, J. M. (1964) Poisonous plants of United States and Canada, Eaglewood Cliff, N.J. Prentice Hall, pp. 23-26.

Lang, K. (1933a) Die Rhodanide-bildung in Tiekorper, Biochem. Ztschr. 259, 243-256.

Lang, K. (1933b) Die Rhodanide-bildung in Tiekorper, Biochem. Ztschr. 263, 263-271.

Lee, C. H., Hwang, J. H., Lee, Y. S. and Cho, K. S. (1995) Purification and characterization of mouse liver rhodanese. $J$. Biochem. Mol. Biol. 28, 170-176.

Lineweaver, H. and Burk, D. (1934) The determination of enzyme dissociation constants. J. Amer. Chem. Soc. 56, 658-666.

Montgomery, R. D. (1965) The medical significance of cyanogens in plant foodstuffs. Amer. J. Clin. Nutr. 17, 103-113.

Mutere, F. A. (1965) The breeding biology of equatorial vertebrates reproduction in the fruit bat, Eidolon helvum, at Latitude $0^{\circ} 20$ N. J. Zool. Land. 153, 153-161.

Nagahara, N. and Nishino, T. (1996) Roles of amino acid residue in the active site of rat liver mercaptopyruvate sulphurtransferase. J. Biol. Chem. 271, 27395-27401.

Oke, O. L. (1973) The mode of cyanogen detoxification in cassava (Manihot spp); in Chronic cassava toxicity, Proceedings of interdisciplinary workshop, pp. 73-87, International Development Centre Monograph (IDRC-010e), London, UK.

Okon, E. E., Umukoro, R. M. and Ajudua, A. (1976) Diurnal variations of the glycogen and fat stores in the liver and breast muscle of fruit bat, Eidolon helvum (Kerr). Physiol. Biochem. 20, 121-123.

Sorbo, B. H. (1951) On the properties of rhodanese. Partial punhcation, inhibitors and intracellular distribution. Acta Chem. Scand. 5, 724-726.

Sorbo, B. H. (1953a) Crystalline Rhodanese (I). Punhcation and Physicachemical Examination. Acta Chem. Scand. 7, 11291136.

Sorbo, B. H. (1953b) Crystalline rhodanese (II). Enzyme catalyzed reaction. Acta Chem. Scand. 7, 1137-1145. 
Stokinger, H. E. (1981) Pattys industrial hygiene and toxicology Clayton, C. D. and Clayton, F. E. (eds.), pp. 1493-2060, John Wiley and Sons, New York, USA.

Tomati, U., Matarese, R. and Federici, G. (1974) Ferredoxin activation by rhodanese. Phytochem. 13, 1703-1706.

Ulmer, D. D. and Vallee, B. L. (1972) Role of metals in sulphurtransferase activity. Ann. Rev. Biochem. 32, 86-90.

Vaughan, T. A. (1972) Functional morphology of three bats. Eumops, myotis, macrotis. Puld. Mus. Natur, Hist. Univ. Kans. $12,1-53$.

Weber, K. and Osborn, M. (1975) Protein and sodium dodecyl sulphate: Molecular weight determination on polyacrylamide gels and related procedures; in The Proteins, Neurath, H. and Hill, R. L. (eds.), pp. 179-223, Academic Press, New York, USA.

Westley, J. (1980) Rhodanese and the sulphane pool, In: Enzymatic basis of detoxification, pp. 245-259, Vol. II, Academic Press, New York, USA.

White, A., Handle, P., Smith, E. L., Hill, R. L. and Lehman, I. R. (1981) Principles of Biochemistry, 6th ed., pp. 391-734, McGraw Hill, Kogakusha, Tokyo, Japan.

Wokes, F. and Willimott, S. G. (1951) The determination of cyanide in seeds. J. Pharm. Pharmacol. 3, 905-916. 